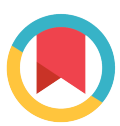

Check for updates

\title{
Association of Serum Vitamin D Level and Serum Lipids Profile
}

\author{
Roxana Sadeghi ${ }^{1}$, Mohammad Reza Eidi ${ }^{~}$, Nasim Zamani ${ }^{2, *}$
}

${ }^{1}$ Cardiovascular Research Center, School of Medicine, Shahid Beheshti University of Medical Sciences, Tehran, Iran

${ }^{2}$ Department of Clinical Toxicology, Loghman Hakim Hospital, Shahid Beheshti

University of Medical Sciences, Tehran, Iran

* Corresponding author: Nasim Zamani, Department of Clinical Toxicology, Loghman Hakim Hospital, Shahid Beheshti University of Medical Sciences, Tehran, Iran.

DOI: $10.21859 / \mathrm{ijcp}-03203$ E-mail: Nasim.zamani@gmail.com

Submited: 01-10-2018

Accepted: 02-13-2018

Keywords:

Vitamin D

Serum Lipid Profile

Dietary Supplements

(C) 2018. International Journal of Cardiovascular Practice.

\section{Abstract}

Introduction: High level of vitamin $\mathrm{D}$ is associated with a better health status. The role of vitamin $\mathrm{D}$ deficiency in the incidence of cardiovascular events is demonstrated in previous studies. The current study aimed at evaluating the effect of vitamin D supplement therapy on serum lipids profile, as a risk factor for cardiovascular diseases.

Methods: The current prospective cohort study included 221 patients admitted to a university hospital from March 2014 to March 2015. The baseline levels of the patients' serum vitamin $\mathrm{D}$ and lipid profile of the study subjects were recorded. After three months treatment with vitamin $\mathrm{D}$, the patients' serum vitamin $\mathrm{D}$ level and lipid profile were reevaluated. The results before and after the supplement therapy were compared using statistical methods.

Results: The mean age of the patients was $48.2 \pm 14.0$ years. The mean vitamin $\mathrm{D}$ level was $21.0 \pm 16.6 \mathrm{ng} / \mathrm{mL}$ at baseline, which increased to $35.8 \pm 32.7 \mathrm{ng} / \mathrm{mL}(\mathrm{P}=0.001)$ after a three-month vitamin D supplement therapy. Mean low-density lipoprotein (LDL) decreased from $112.1 \pm 30.0$ to $98.7 \pm 31.7 \mathrm{mg} / \mathrm{dL}(\mathrm{P}=0.003)$ after the supplement therapy. Mean high-density lipoprotein (HDL) increased from $42.8 \pm 11.2$ to $44.5 \pm$ $9.0 \mathrm{mg} / \mathrm{dL}$, but the difference was insignificant before and after the treatment $(\mathrm{P}=0.2)$. Mean cholesterol reduced from $183.8 \pm 42.3$ to $169.5 \pm 41.9 \mathrm{mg} / \mathrm{dL}(\mathrm{P}=0.02)$ and the mean TG dropped from $147.5 \pm 98.7$ to $134.7 \pm 71.1 \mathrm{mg} / \mathrm{dL},(\mathrm{P}=0.1)$ after vitamin $\mathrm{D}$ intake.

Conclusions: The mean levels of LDL and cholesterol significantly decreased during the three-month intervention; in addition, although some changes were observed in the level of HDL and TG, the differences were statistically insignificant. Further studies on larger sample sizes and longer follow-ups are recommended.

\section{INTRODUCTION}

Vitamin D is one of the main causes of homeostasis in the bone and minerals. This vitamin increases the gastrointestinal absorption of the calcium and prevents/treats rickets [1]. On the other hand, the vitamin $\mathrm{D}$ receptors are spread throughout the body and therefore, extraskeletal effects of vitamin D are predictable [2]. Thus, along with the development of different methods to measure $25(\mathrm{OH}) \mathrm{D}$, which is the most common metabolite of vitamin $\mathrm{D}$, several studies were performed to evaluate the level of this vitamin and according to their results, higher levels of vitamin $\mathrm{D}$ is associated with a better health status. Therefore, the lower levels of this vitamin can be considered as a predictor for type 2 diabetes mellitus, cancer, cardiovascular disorders, immunological problems, and mortality [3]. In a 11-year study on 4751 patients, subjects with lower levels of $25(\mathrm{OH})$ D were about 32 times more at risk of mortality, compared with the ones with higher levels of $25(\mathrm{OH})$ $\mathrm{D}$ [4]. In another study on 1739 patients from the offspring of the Framingham study, those with serum vitamin D levels of lower than $15 \mathrm{ng} / \mathrm{mL}$ had a risk ratio of 1.8 to cardiovascular events compared with those with $15 \mathrm{ng} / \mathrm{mL}$ serum vitamin $\mathrm{D}$ or more [5]. These studies suggested the use of vitamin D supplements to improve the general health status [6]. Association of vitamin $\mathrm{D}$ and cardiovascular disorders may be due to the role of this vitamin in decreasing the serum lipid levels confirmed by some cross sectional studies [7-9]. The current controlled trial aimed at evaluating the effect of vitamin D on the serum lipid levels, and examining the impact of vitamin D administration on the decrease of serum lipid levels. 


\begin{tabular}{|lccc|}
\hline \multicolumn{2}{|c|}{ Table 1: Comparison of the Mean Levels of Vitamin D and Lipid Profile, before and after Vitamin D Supplement Therapy } \\
Vitamin level (ng/ml) & Before therapy & After therapy & Pvalue \\
LDL (mg/dl) & $21.0 \pm 16.6$ & $35.8 \pm 32.7$ & 0.001 \\
HDL $(\mathbf{m g} / \mathbf{d l})$ & $112.1 \pm 30.0$ & $98.7 \pm 31.7$ & 0.003 \\
TG (mg/dl) & $42.8 \pm 11.2$ & $44.5 \pm 9.0$ & 0.2 \\
Cholesterol (mg/dl) & $147.5 \pm 98.7$ & $134.7 \pm 71.1$ & 0.1 \\
\hline
\end{tabular}

Data in table are presented as Mean \pm SD

LDL, Low density lipoprotein; HDL, High density lipoprotein; TG,Triglyceride

\section{METHODS}

In a prospective, cross sectional study, all the patients above 18 years old referring to Cardiology Clinic of Loghman-Hakim Hospital from March 2014 to March 2015 were prospectively included. The study protocol was approved by the Ethical Committee of Shahid Beheshti University of Medical Sciences, Tehran, Iran. On arrival, a blood sample was taken from all patients in order to measure the basal level of $25(\mathrm{OH})$ $\mathrm{D}$, the most valid metabolite of vitamin $\mathrm{D}$. The basal levels of the patients' lipid profile were also recorded. Other variables including age, gender, and coronary risk factors were determined and recorded. The patients then underwent a therapeutic regimen including a weekly administration of vitamin D $50000 \mathrm{U}$ for three months. In the follow-up visit three months after the treatment, a blood sample was retaken and 1,25 hydroxyvitamin D and lipid profile were studied in all the subjects.

\section{Statistics}

The data are expressed as mean \pm standard deviation (SD), and the categorical variables as percentages. Continuous variables were compared by the Student $t$ test or the Mann-Whitney $U$ test, based on the distribution of data. Finally, the data were analyzed with SPSS version 19. A P-value $<0.05$ was considered statistically significant.

\section{RESULTS}

A total of 221 patients referred to the Cardiology Clinic of Loghman-Hakim Hospital were enrolled in the study. The patients were put on vitamin D supplement. After three months of supplement therapy, only 50 patients including 21 (42\%) males and 29 (58\%) females referred for the follow-up visit. The mean age of the patients was $48.2 \pm 14.0$ years. The mean vitamin D level was $21.0 \pm 16.6 \mathrm{ng} / \mathrm{mL}$ on admission. After supplement therapy, the mean vitamin $\mathrm{D}$ level increased to $35.8 \pm 32.7 \mathrm{ng} / \mathrm{mL}(\mathrm{P}=0.001)$. Mean low-density lipoprotein $(\mathrm{LDL})$ decreased from $112.1 \pm 30.0$ to $98.7 \pm 31.7 \mathrm{mg} / \mathrm{dL}$ $(\mathrm{P}=0.003)$. Mean high-density lipoprotein $(\mathrm{HDL})$ increased from $42.8 \pm 11.2$ to $44.5 \pm 9.0 \mathrm{mg} / \mathrm{dL}(\mathrm{P}=0.2)$. Mean cholesterol dropped from $183.8 \pm 42.3$ to $169.5 \pm 41.9 \mathrm{mg} / \mathrm{dL}(\mathrm{P}=$ 0.02 ), and the mean triglyceride (TG) reduced form $147.5 \pm$ 98.7 to $134.7 \pm 71.1 \mathrm{mg} / \mathrm{dL},(\mathrm{P}=0.1)$ (Table 1$)$.

\section{DISCUSSION}

The results of the current study showed that the mean lev- els of LDL and cholesterol significantly decreased during the three-month of supplement therapy. Although HDL and TG were changed, it was not statistically significant. Different mechanisms are proposed as the protective factors of vitamin $\mathrm{D}$ in heart failure. Serum level of $25(\mathrm{OH}) \mathrm{D}$ is a significant factor showing the vitamin $\mathrm{D}$ reservoir of the body [10]. Receptor of vitamin D3 (calcitriol) exists in many of the cells including cardiomyocytes, endothelial cells, neurons, and immunological cells $[10,11]$. Calcitriol is one of the most important regulators of the calcium metabolism and serum calcium homeostasis. Also, it acts as the cytokine excretion and intra-cellular calcium metabolism regulator [10-12]. Serum lipid levels have also an important role in the calcium metabolism. As previously described, calcium intake affects the body mass index (BMI) in different ways, the easiest of which, is the inhibition of lipid and free fatty acid absorption [13]. It seems that the most important effect of calcium is on the extracellular calcium control. Based on the results of different studies, agouti gene is a stimulator of calcium in the lipid tissue, which affects the lipolysis and lipogenesis and increases the lipid storage in the lipid tissue [14]. Calcitriol increases the synthesis of fatty acids and inhibits the calcium-dependent lipolysis [15]. Then, entrance of calcium into the cells by calcitriol is decreased. Higher intake of calcium, decreases the calcium entrance by 1 and 25 dihydroxycholecalciferol, inhibits the synthesis of fatty acids, and triggers the lipolytic activity [15]. Decreased plasma insulin by diet calcium is another mechanism of this effect. Insulin secretion is calcium-dependent and increased calcium is necessary to both first and second phases of insulin secretion [16]. Calcium also plays an important role in glucose uptake by binding to the skeletal cells receptors, insulin receptor affinity, and insulin sensitivity [17]. In a review study by Hao Wang et al., on 12 clinical trials, the mean change of LDL was $3.23 \mathrm{mg}$ / $\mathrm{dL}(0.55$ to $5.90 \mathrm{mg} / \mathrm{dL})$, while no changes were detected in the level of total cholesterol, TG, and HDL after the administration of vitamin D. However, they suggested further studies to confirm the effect of vitamin D on serum lipid profile [18]. As observed, results of their study were consistent with those of the current study in terms of LDL, HDL, and TG, except for cholesterol, which significantly decreased in the current study.

In a cross sectional study by Manish et al., a total of 107,811 patients were serially evaluated from 2009 to 2011. Their results showed that the patients with vitamin $\mathrm{D}$ deficiency (serum level less than $20 \mathrm{ng} / \mathrm{mL}$ ) had lower total cholesterol, LDL, and TG, and higher HDL levels compared with those with normal levels of vitamin D. Their study also found that 
increment in the level of vitamin D from 20 to $30 \mathrm{ng} / \mathrm{mL}$ increased the cholesterol, and HDL significantly compared with those of the ones with vitamin D levels lower than 20 $\mathrm{ng} / \mathrm{mL}$ [19]. Arslanian et al., showed that vitamin D deficiency was associated with higher lipid and lower HDL in both white and African-American children. According to their results, $40 \%$ of the white children and $73 \%$ of the African-American children had vitamin D deficiency. A reverse relation was found between the concentration of 25 hydroxyvitamin D and BMI, total body fat, visceral adipose tissue (VAT), and subcutaneous adipose tissue (SAT), while a direct relation was observed between 25 hydroxyvitamin $\mathrm{D}$ and HDL. White children with vitamin D deficiency had a higher VAT compared with those without vitamin D deficiency, while SAT level was higher in the black children without vitamin D deficiency. Race, season, puberty, and VAT were reported as other factors contributing 25 hydroxyvitamin $\mathrm{D}$ deficiency. Vitamin $\mathrm{D}$ deficiency is more common in blacks and females. They concluded that decreased vitamin $\mathrm{D}$ level is accompanied by much higher lipid accumulation and decreased level of HDL. They therefore suggested that the treatment of vitamin D deficiency can affect lipid tissue and lipid profile of children and reduce the risk of type 2 diabetes mellitus [20].

A study by Schleithoff et al., evaluated the adjusting effects of vitamin D on inflammation. They showed that after a nine-month treatment with vitamin $\mathrm{D}$ in patients with heart failure, the inflammatory cytokine of tumor necrosis factor (TNF)- $\alpha$ decreased and anti-inflammatory cytokine of interleukin (IL)-10 increased [21]. In a study by Zittermann et al., serum level of vitamin D was significantly lower in patients with heart failure compared with the controls [22]. Witte et al., showed that low serum level of vitamin D is associated with the myocyte dysfunction, heart failure, and subsequently, acute cardiac death [23]. Many studies showed that in patients with metabolic syndrome, vitamin D level is lower, while some other studies rejected this hypothesis. In a study on 1654 Americans, [24-26] the lower levels of vitamin $\mathrm{D}$ was observed in patients with metabolic syndrome; the result was in agreement with those of some other studies. In a study by Moy on 380 individuals, subjects with vitamin $\mathrm{D}$ deficiency were at higher risk for the development of metabolic syndrome ( $\mathrm{OP}=1.73$ ); in addition, $\mathrm{BMI}$, waist circumference, and TG level were significantly different among the ones with normal and vitamin D deficiency [27]. In a study in China on 3262 people, the risk of metabolic syndrome was almost 1.52 times higher in the ones at the lowest quartile of vitamin $\mathrm{D}$ compared with the ones on the highest quartile. A significant diverse relation was observed between metabolic syndrome and level of vitamin D [28]. The most important limitations of the current study were the small sample size and lack of control group. Also, the study selected patients who referred to a cardiology clinic; therefore, the generalization of the results should be done cautiously.

\section{CONCLUSIONS}

Treatment with vitamin D can significantly decrease the level of LDL and cholesterol in the patients, although it has no impact on the level of TG and HDL. Other prospective studies on the contributing risk factors are suggested in order to evaluate the impact of vitamin $\mathrm{D}$ level on lipid profile.

\section{AUTHOR CONTRIBUTIONS}

Design: Roxana Sadeghi

Data collection: Mohammad Reza Eidi

Data analysis and interpretation: Nasim Zamani

Drafting the article: Roxana Sadeghi

Final writing and submitting: Nasim Zamani

\section{CONFLICTS OF INTEREST}

None

\section{REFERENCES}

1. DeLuca HF. Overview of general physiologic features and functions of vitamin D. Am J Clin Nutr. 2004;80(6 Suppl):1689S-96S. PMID: 15585789

2. Maalouf NM. The noncalciotropic actions of vitamin D: recent clinical developments. Curr Opin Nephrol Hypertens. 2008; 17(4):408 15. DOI: 10.1097/MNH.0b013e3283040c99 PMID: 18660678

3. Holick MF. Vitamin D deficiency. N Engl J Med. 2007;357(3):266 81. DOI: 10.1056/NEJMra070553 PMID: 17634462

4. Hutchinson MS, Grimnes G, Joakimsen RM, Figenschau Y, Jorde R. Low serum 25-hydroxyvitamin D levels are associated with increased all-cause mortality risk in a general population: the Tromso study. Eur J Endocrinol. 2010;162(5):935-42. DOI: 10.1530/EJE-09-1041 PMID: 20185562

5. Wang TJ, Pencina MJ, Booth SL, Jacques PF, Ingelsson E, Lanier K et al. Vitamin D deficiency and risk of cardiovascular disease. Circulation. 2008;117(4):503-11. DOI: 10.1161/CIRCULATIONAHA.107.706127 PMID: 18180395

6. Lips P. Worldwide status of vitamin D nutrition. J Steroid Biochem Mol Biol. 2010;121(1-2):297-300. DOI: 10.1016/j. jsbmb.2010.02.021 PMID: 20197091

7. Jorde R, Figenschau Y, Hutchinson M, Emaus N, Grimnes G. High serum 25-hydroxyvitamin $\mathrm{D}$ concentrations are associated with a favorable serum lipid profile. Eur J Clin Nutr. 2010;64(12):1457-64 DOI: $10.1038 /$ ejcn.2010.176 PMID: 20823896

8. Jorde R, Grimnes G. Vitamin D and metabolic health with special reference to the effect of vitamin D on serum lipids. Prog Lipid Res. 2011;50(4):303-12. DOI: 10.1016/j.plipres.2011.05.001 PMID: $\underline{21640757}$

9. Zittermann A, Gummert JF, Borgermann J. The role of vitamin $\mathrm{D}$ in dyslipidemia and cardiovascular disease. Curr Pharm Des. 2011;17(9):933-42. PMID: 21418036

10. Zittermann A, Schleithoff SS, Koerfer R. Vitamin D insufficiency in congestive heart failure: why and what to do about it? Heart Fail Rev. 2006;11(1):25-33. DOI: 10.1007/s10741-006-9190-8 PMID: 16819575

11. Zittermann A, Schleithoff SS, Koerfer R. Putting cardiovascular disease and vitamin D insufficiency into perspective. Br J Nutr. 2005;94(4):483-92. PMID: 16197570

12. De Boland AR, Boland RL. Non-genomic signal transduction pathway of vitamin D in muscle. Cell Signal. 1994;6(7):717-24. PMID 7888298

13. Welberg JW, Monkelbaan JF, de Vries EG, Muskiet FA, Cats A, Oremus ET, et al. Effects of supplemental dietary calcium on quantitative and qualitative fecal fat excretion in man. Ann Nutr Metab. 1994;38(4):185-91. DOI: 10.1159/000177810 PMID: 7832578

14. Comuzzie AG, Allison DB. The search for human obesity genes. Science. 1998;280(5368):1374-7. PMID: 9603720

15. Shi H, Dirienzo D, Zemel MB. Effects of dietary calcium on adipocyte lipid metabolism and body weight regulation in energy-restricted aP2-agouti transgenic mice. FASEB J. 2001;15(2):291-3. DOI: 10.1096/fi.00-0584fje PMID: 11156940

16. Henquin JC, Ravier MA, Nenquin M, Jonas JC, Gilon P. Hierarchy of the beta-cell signals controlling insulin secretion. Eur J Clin Invest. 2003;33(9):742-50. PMID: 12925032

17. Williams PF, Caterson ID, Cooney GJ, Zilkens RR, Turtle JR. High affinity insulin binding and insulin receptor-effector coupling: modulation by Ca2+. Cell Calcium. 1990;11(8):547-56. PMID: 1702365

18. Wang H, Xia N, Yang Y, Peng DQ. Influence of vitamin D supplementation on plasma lipid profiles: a meta-analysis of randomized con- 
trolled trials. Lipids Health Dis. 2012;11:42. DOI: 10.1186/1476511X-11-42 PMID: 22433171

19. Ponda MP, Huang X, Odeh MA, Breslow JL, Kaufman HW. Vitamin D may not improve lipid levels: a serial clinical laboratory data study. Circulation. 2012;126(3):270-7. DOI: 10.1161/CIRCULATIONAHA.111.077875 PMID: 22718799

20. Rajakumar K, de las Heras J, Chen TC, Lee S, Holick MF, Arslanian SA. Vitamin D status, adiposity, and lipids in black American and Caucasian children. J Clin Endocrinol Metab. 2011;96(5):1560-7. DOI: $10.1210 /$ jc.2010-2388 PMID: 21367931

21. Schleithoff SS, Zittermann A, Tenderich G, Berthold HK, Stehle P, Koerfer R. Vitamin D supplementation improves cytokine profiles in patients with congestive heart failure: a double-blind, randomized, placebo-controlled trial. Am J Clin Nutr. 2006;83(4):754-9. PMID: $\underline{16600924}$

22. Zittermann A, Schleithoff SS, Tenderich G, Berthold HK, Korfer R, Stehle P. Low vitamin D status: a contributing factor in the pathogenesis of congestive heart failure? J Am Coll Cardiol. 2003;41(1):10512. PMID: 12570952

23. Witte KK, Clark AL, Cleland JG. Chronic heart failure and micronu- trients. J Am Coll Cardiol. 2001;37(7):1765-74. PMID: 11401109

24. Reis JP, von Muhlen D, Miller ER, 3rd. Relation of 25-hydroxyvitamin $\mathrm{D}$ and parathyroid hormone levels with metabolic syndrome among US adults. Eur J Endocrinol. 2008;159(1):41-8. DOI: 10.1530/EJE08-0072 PMID: 18426812

25. Hypponen E, Boucher BJ, Berry DJ, Power C. 25-hydroxyvitamin D, IGF-1, and metabolic syndrome at 45 years of age: a cross-sectional study in the 1958 British Birth Cohort. Diabetes. 2008;57(2):298305. DOI: $10.2337 / \mathrm{db} 07-1122$ PMID: 18003755

26. Ford ES, Ajani UA, McGuire LC, Liu S. Concentrations of serum vitamin $\mathrm{D}$ and the metabolic syndrome among U.S. adults. Diabetes Care. 2005;28(5):1228-30. PMID: 15855599

27. Moy FM, Bulgiba A. High prevalence of vitamin D insufficiency and its association with obesity and metabolic syndrome among Malay adults in Kuala Lumpur, Malaysia. BMC Public Health. 2011;11:735. DOI: 10.1186/1471-2458-11-735 PMID: 21943301

28. Lu L, Yu Z, Pan A, Hu FB, Franco OH, Li H, et al. Plasma 25-hydroxyvitamin $\mathrm{D}$ concentration and metabolic syndrome among middle-aged and elderly Chinese individuals. Diabetes Care. 2009;32(7):1278-83. DOI: 10.2337/dc09-0209 PMID: 19366976 